\title{
Home Sanitary Improvements Program as Vector of Change in the Brazilian Public Health Scenario: A Strategy for the Fulfillment of a Human Right
}

\author{
André Preissler Loureiro Chaves ${ }^{1,2 *}$, Bruna de Souza Fontela ${ }^{3}$, Márcia Maria Nascimento de \\ Almeida $^{4}$, Albert Welzel ${ }^{5}$ \\ ${ }^{I}$ Ph.D in Public Health by Faculty of Public Health, Universidade de Sao Paulo (USP), Sao Paulo, SP, Brazil \\ ${ }^{2}$ Post-doctor by University of Surrey, Centre for Environment and Sustainability (CES), Guildford, Surrey, UK \\ ${ }^{3}$ Universidade Luterana do Brasil. Graduated in Environmental Engineering, Canoas, RS, Brazil \\ ${ }^{4}$ Universidade Federal da Bahia. Graduated in Sanitary Engineering. Salvador, Bahia, Brasil \\ ${ }^{5}$ Universidade Luterana do Brasil. Department of Environmental and Sanitary Engineering. Canoas, RS, Brasil \\ *Corresponding Author: Andre Preissler Loureiro Chaves, Visiting Research Fellow, Centre for \\ Environment and Sustainability (CES), University of Surrey (UoS), Guildford, Surrey, UK. Email: \\ andreplc@terra.com.br
}

\begin{abstract}
Introduction: The Brazilian Home Sanitary Improvements Program (HSIP) intends to intervene in homes, attending to basic necessities of sanitation, in municipalities up to 50.000 inhabitants. The present study analyzed the relationship between the HSIP and its benefits to population's life quality, and the National Health Foundation's role as an induction vector for public politics in the sector.

Methods: The study collected data, through questionnaires, in five of 29 municipalities from the State of Rio Grande do Sul that have been using HSIP between 2008-2015. To the municipality of Mostardas, interviews were conducted. The data obtained through the questionnaires and interviews were treated by the Content Analysis.

Results: It was possible to infer an improvement on sanitary conditions, and resulting reduction of environmental contamination. However, the population of Mostardas showed discontentment towards the quality of the sanitary modules and the way as the program was conducted in their homes. With regard to the Municipality Sanitation Workshop (MSW), central to full development of the HSIP, there were no evidences of its implantation.
\end{abstract}

Conclusion: HSIP can be an alternative to conventional solutions when associated with use of educational and social structures. FUNASA, in its current template of acting, partially fulfill its role.

Keywords: Environmental Health; Public Health; Home Sanitary Improvements; Appropriate Technology; Basic Sanitation

\section{INTRODUCTION}

In 2007, the British Medical Journal (BMJ) said after conducting research with more than 11 miles of its readers that it is sanitation for the greatest technological advancement in the public health area of the last 150 years, overcoming a discovery of the antibiotic and an invention of Vaccines[1]. Britto[2] states that there are risks related to climate change can be associated with four phenomena: in the atmospheric conditions, in the most frequent and/or intense rains, the occurrence of droughts or storms and and changes in sea level. All these phenomena affect sanitation and its management: the increase in temperatures generates an increase in the demand for water, which can lead to problems in the quality of water sources. Increasing the frequency or intensity of rainfall, and overloading the drainage system, may jeopardize existing infrastructure for water supply, sewage collection, and the contamination of groundwater and surface water sources.

The sanitation situation has immediate repercussions on health indicators. It is estimated that $65 \%$ of hospitalizations of 
children under 10 years old are caused by maladies arising from the lack of sewer and clean water. Access to this service also has an effect on school performance, since children living in areas without basic sanitation have $18 \%$ lower school achievement than those with access[3]. In 2013, the cost of hospitalization for gastrointestinal infection in the Brazilian Unified Health System (SUS) was about R\$ 355.71 per patient in the national average[4]. This resulted in public expenditures for hospitals of R \$ 121 million a year, just to treat the infected people. The reduction of cases that could be obtained with the universalization of sanitation, therefore, would lead to a significant reduction of costs for SUS.

Negative interactions between lack of sanitation and environmental impacts are felt at all levels of an ecosystem. In the event that sewage, for example, not being correctly disposed of or not adequately treated, may lead to deterioration of the receiving body (rivers, lakes and seas), to impair aquatic life through eutrophication and to harm animal and vegetables species in the region that interact with the affected site[5]. It will also affect soil production capacity, interfering with the fragile balance of nutrients needed to maintain production and correlated activities, and may lead to soil contamination of groundwater reserves.

During the United Nations Summit on Sustainable Development in September 2015, the Sustainable Development Goals (SDG) were presented to member states. The SDG is a global agenda composed of 17 goals to be achieved by 2030[6]. The SDG6 is defined as "ensuring the availability and sustainable management of water and sanitation for all". The goals are to equitably distribute water to the world's population and improve its quality by reducing pollution and restoring ecosystems, eliminating dumping and minimizing the release of hazardous chemicals, reducing the proportion of untreated wastewater by half[6].

The use of sanitation as a tool to promote health requires overcoming the technological, political and managerial obstacles that have hampered the extension of the benefits to residents in rural areas and municipalities with a population of up to 50,000 inhabitants[7]. In Brazil, sanitation is a right guaranteed since 1988 by the Federal Constitution[8,9]. In order to regulate and promote sanitation, in 1991, was raised the
National Health Foundation (FUNASA), an executive body of the Ministry of Health of Brazil and responsible for promoting social inclusion through sanitation actions[10].

This government agency develops programs based on conventional sanitation actions, such as water supply and treatment networks and sewage treatment networks, and nonconventional programs based on individualized or collective actions of small size, known as the Home Sanitary Improvements Program (HSIP). The HSIP aims to take sanitation to hard-toreach locations, to low-income families or in situations where conventional action is ineffective, using appropriate technologies to solve the particularity of each situation. It seeks to provide households with sanitary improvements, necessary to protect families and promote hygienic habits, and encourages the implementation of Municipal Sanitation Workshops (MSW)[10].

MSW carries out surveys of health and epidemiological conditions, mapping environmental risk factors and identifying actions to be developed. It seeks to plan with the community, together with the municipal health manager, the sanitation actions, emphasizing the elaboration of the Municipal Sanitation Plan (MSP), in articulation with the other local public policies. One of its main guidelines is the search for alternatives to projects and technical, political, administrative and financial solutions for the implementation of the actions indicated in the MSP.

The workshop serves as a space for capacity building of leaders, community health agents and professionals involved in the implementation, evaluation and follow-up of the MSP. It works together with the population aiming at the implementation, use and maintenance of small-scale household and collective health improvements. It also provides for health and environmental education activities, as well as communication, aimed at understanding sanitation actions[11].

Merhy[12] proposes to visualize operational practices to understand the productive structure of the health sector, considering the technologies and knowledge of users through toolboxes. The first box is that of the preparation and procedures, the second of the knowledges, and the third is the relationship between health workers and users. This view questions the hegemonic model of the current 
sanitation that disregards the user, and proposes the classification of work in dead and alive: dead work is what is available at the time of sanitation acts, but has already been produced previously; live work is what happens in act, at the moment of the encounter between workersusers and that responds to the singularity of the situations. It is not only on the scientific level that the production of knowledge takes place, also occurring in the level of user experience[13,14].

But why use HSI? When is this action effective? Can simple construction of toilets, septic tanks and sinks or access to environmental education programs be considered the first step to improve the Brazilian sanitary scenario? In this context, the present study has as general objective to analyze the relationship between the Home Sanitary Improvements Program (HSIP/FUNASA) and its benefits to public health, the environment and the quality of life of the population, showing them as economic and technically feasible in addition to conventional solutions.

\section{Materials AND Methods}

\subsection{Sample Size and Sampling Strategy}

The study was designed from the methodological perspective of triangulation, involving three different social actors: municipal managers responsible for the implementation of the program, specialists and technicians in sanitation and public health, and beneficiary population of the Home Sanitary Improvements Program.

The State of Rio Grande do Sul, Brazil, in partnership with FUNASA, has been using HSIP since 2008 in 29 municipalities. Among these municipalities, 5 declared their works as completed by December 2015, in a total investment of $\mathrm{R} \$ 1,505,618.00[3]$.

To all the 29 municipalities a questionnaire was sent to the Secretariats of Works, Environment and Health, by email and mail, seeking to identify the effectiveness of the HSIP as a sanitation action, and also to analyze the reason for choosing HSI versus conventional solutions. Of the 29 municipalities contacted, responses were obtained from 05 towns: Alegria, Caiçara, Mostardas, Porto Lucena and São Miguel das Missões.

In the municipality of Mostardas, interviews were carried out with 7 beneficiaries, among
134 participants of the HSIP. The beneficiaries were selected based on information from the Final Report of the HSI Project sent us by the municipality's Secretary of Works. Previously, we tried to locate the addresses through the Google Maps tool, in order to determine a route to be followed in the field. Contact with the city hall was made, in order to define the best days for the interviews and which areas would be more accessible, aiming the activities planning and data quality. In the definition for two days in the field, September 10 and 11, 2016, we considered the time for the interviews, the availability of the city hall and the best time to find the beneficiaries. Of the 134 beneficiaries listed in the report, 59 were not located due to the outdated listing or divergence of address of the property that received the benefit. Of the 75 addresses found, 46 residences were visited, where 7 beneficiaries agreed to participate.

Information was also obtained from three experts on Sanitation and Public Health, which work in different parts of the country (Bahia, Ceará and Rio Grande do Sul), to evaluate the actions of HSI from a technical-political perspective.

\subsection{Data Collection Instruments}

A questionnaire sent to the Secretariats of Works, Environment and Health of the 29 municipalities was trying to prospect this topics: (1) to identify the sanitary situation of the municipality, (2) to know the major challenges and difficulties encountered for the implementation of the HSIP and how to remedy them, and (3)advantages in using HSI versus other alternatives.

To the survey with the population benefited by HSI, in the municipality of Mostardas, a semistructured interview script was applied, probing: (1) the population's view of the HSIP, (2) the implications of the program, whether or not they are beneficial; (3) understanding of the relationships between basic sanitation, environment and public health, (4) degree of community involvement during the HSIP implementation. The audio content was recorded and subsequently de-grained to perform the analysis of the data obtained.

The data collection with the technician of the Department of Engineering and Public Health of FUNASA/RS was given through a semistructured interview script. The audio content was later transcripted to perform its analysis, with the purpose of knowing: (1) the importance 
of HSIP, (2) difficulties identified for its development and (3) how to guarantee its efficiency. A second technician from FUNASA (State of Ceará) and a professional in the field of sanitation (State of Bahia) were contacted via email, using a questionnaire, to identify: (1) the relationship between sanitation, public health and the environment, (2) the importance of user participation, and (3) the need for an environmental education program to ensure the effectiveness of HSIP.

\subsection{Data Analysis}

The data obtained through the questionnaires and interviews were treated by the Content Analysis technique which, according to Cavalcante[15], Bardin[16] and Campos[17], provide a model of deep understanding of elemental connections, grounding the understanding of the manifestation of the object of study.With the pre-analyzed content, the exploration was carried out of the transcripts of the interviews with technicians of FUNASA and beneficiaries of the municipality of Mostardas, besides the texts of the questionnaires sent by the municipalities and other professional of the sanitation. In order to categorize the results and the frequency counting of discourse patterns, a table was created identifying each participant (Table 1).

Table1. Participant Coding System

\begin{tabular}{|c|c|c|}
\hline Characterization & Participant & Identification \\
\hline \multirow{5}{*}{$\begin{array}{l}\text { City Halls } \\
\text { (Secretariats of } \\
\text { Works, } \\
\text { Environment and } \\
\text { Health) }\end{array}$} & $\begin{array}{l}\text { Municipality } \\
\text { of Alegria }\end{array}$ & M1 \\
\hline & $\begin{array}{l}\text { Municipality } \\
\text { of Caiçara }\end{array}$ & M2 \\
\hline & $\begin{array}{l}\text { Municipality } \\
\text { of Porto } \\
\text { Lucena }\end{array}$ & M3 \\
\hline & $\begin{array}{l}\text { Municipality } \\
\text { of } \quad \text { São } \\
\text { Miguel das } \\
\text { Missões }\end{array}$ & M4 \\
\hline & $\begin{array}{l}\text { Municipality } \\
\text { of Mostardas }\end{array}$ & M5 \\
\hline \multirow{7}{*}{$\begin{array}{l}\text { Benefited } \\
\text { Population } \\
\text { (Municipality of } \\
\text { Mostardas) }\end{array}$} & Interviewee 1 & Int1 \\
\hline & Interviewee 2 & Int2 \\
\hline & Interviewee 3 & Int3 \\
\hline & Interviewee 4 & Int4 \\
\hline & Interviewee 5 & Int5 \\
\hline & Interviewee 6 & Int6 \\
\hline & Interviewee 7 & Int7 \\
\hline \multirow{3}{*}{$\begin{array}{l}\text { Sanitation } \\
\text { Experts }\end{array}$} & FUNASA RS & ExpRS \\
\hline & FUNASA CE & ExpCE \\
\hline & $\begin{array}{l}\text { Sanitation } \\
\text { Professional } \\
\text { BA }\end{array}$ & ExpBA \\
\hline
\end{tabular}

In order to support the inference and interpretation of the results, it was decided to develop Table 2, summarizing and condensing the main topics to be analyzed.

Table2. Main topics to be analyzed and their purposes

\begin{tabular}{|l|l|}
\hline \multicolumn{1}{|c|}{ Main topics } & \multicolumn{1}{c|}{ Purposes } \\
\hline $\begin{array}{l}\text { Relations } \\
\text { between } \\
\text { sanitation, } \\
\text { environment } \\
\text { and health }\end{array}$ & $\begin{array}{l}\text { To show the relations between } \\
\text { the three dimensions and their } \\
\text { anterconnection and importance } \\
\text { as a set of actions }\end{array}$ \\
\hline $\begin{array}{l}\text { Sanitary } \\
\text { situation of } \\
\text { participating } \\
\text { municipalities }\end{array}$ & $\begin{array}{l}\text { To characterize the situation of } \\
\text { the municipality before and } \\
\text { after HSIP, seeking to evaluate } \\
\text { its effectiveness }\end{array}$ \\
\hline $\begin{array}{l}\text { Feasibility of } \\
\text { using HSI } \\
\text { versus } \\
\text { conventional } \\
\text { solutions }\end{array}$ & $\begin{array}{l}\text { To show in which situations } \\
\text { one can opt for HSI and find } \\
\text { evidence that supports the HSI } \\
\text { versus conventional solutions }\end{array}$ \\
\hline $\begin{array}{l}\text { Implementation } \\
\text { of MSW in } \\
\text { parallel to the }\end{array}$ & $\begin{array}{l}\text { Reinforce the importance of } \\
\text { MSW to the target population } \\
\text { in terms of local environmental } \\
\text { health }\end{array}$ \\
\hline $\begin{array}{l}\text { Role of } \\
\text { FUNASA in } \\
\text { the Brazilian } \\
\text { sanitary } \\
\text { scenario }\end{array}$ & $\begin{array}{l}\text { To identify FUNASA as a } \\
\text { vector of change for the } \\
\text { Brazilian Public } \\
\text { scenario Health }\end{array}$ \\
\hline
\end{tabular}

For the questions that inquired the municipalities about their sanitary conditions, a "Scale of Concepts" was offered: poor, bad, regular/intermediate, good and great. Due to methodological rigor, it was decided to specify the criteria corresponding to each condition, allowing a better analysis of the findings (Table 3).

Table3. Definition of Sanitary Conditions

\begin{tabular}{|l|l|}
\hline \multicolumn{1}{|c|}{$\begin{array}{c}\text { Sanitary } \\
\text { Condition }\end{array}$} & \multicolumn{1}{|c|}{ Criterion } \\
\hline \multirow{2}{*}{ Poor } & $\begin{array}{l}\text { Without water supply and } \\
\text { sewage collection network, } \\
\text { without solid waste } \\
\text { management without urban } \\
\text { drainage project }\end{array}$ \\
\hline Bad & $\begin{array}{l}\text { Only with one of the services, in } \\
\text { a precarious working condition }\end{array}$ \\
\hline Intermediate & $\begin{array}{l}\text { One or two of the services } \\
\text { running on a regular basis }\end{array}$ \\
\hline Good & $\begin{array}{l}\text { More than two services working } \\
\text { in good conditions and } \\
\text { efficiently }\end{array}$ \\
\hline Great & $\begin{array}{l}\text { The four services in optimal } \\
\text { conditions of conservation and } \\
\text { efficiency }\end{array}$ \\
\hline
\end{tabular}


This scale of concepts was adapted from the archives of the Court of Accounts of the State of Rio Grande do Sul, which uses it to evaluate the efficiency of the Municipal Basic Sanitation Plan (MBSP)[18].

Two pillars support the validity and reliability of the data: the triangulation between three different and complementary perspectives and the characteristic of qualitative studies, the saturation point, when the information begins to repeat itself without the addition of new evidences.

\subsection{Ethical Considerations}

In all situations, the Informed Consent Form (ICF) was presented, assuring respondents that they could withdraw their participation at any time. The research project was approved by the Ethics Committee in Research (CEP) of the Lutheran University of Brazil, under CAEE case number 58300016.1.0000.5349.

\section{RESULTS AND DISCUSSION}

\subsection{The Relationship between the HSIP and its Benefits to Population: Sanitation, Environment and Health}

The relationship between basic sanitation, Public Health and the environment is one of the key points of this research. In order to approach it, we used the data collected in the discourses of the beneficiary population, in Mostardas, through the questioning if they would observe some association and which would be. To the sanitation professional and the FUNASA technicians, the same survey was carried out. In the speech of Int4, this understanding is recognized:"It has relation, for sure. My son got sick because he played with sewage when a pipe broke out here. He took a very strong bacterium and had to stay 2 months in hospital".

\section{As with participant interview Int7:}

Yes you do. You can get sick, even child, that just take a shower and they are already playing in the puddles, and we do not even know what's inside. Imagine doing this with open-air sewage? Before they built things here, the sewage was all open-air.

It was possible to identify that the beneficiary population was aware of the connection between these dimensions, especially the association between lack of sanitation and the prevalence of waterborne diseases, due to exposure to open-air sewage near their homes. One of the principles recommended by FUNASA, which guide the HSIP, is to contribute to the reduction of morbidity and mortality rates caused by the lack or inadequacy of home sanitation conditions. In 2016, the Health Department of the State of Rio Grande do Sul released data on infant mortality in 2015, compared to 2014, showing a drop in the index, with 10.1 deaths for every thousand births. In 2016, the newspaper Correio do Povo[19]reported:

The reduction in the Rio Grande do Sul State's Infant Mortality Coefficient (IMC) has even exceeded the agreed goal of the Millennium Development Goals (MDGs), which was intended to achieve a IMC of 15.7 by 2015 at the national level. Some municipalities had a sharp drop in the ratio from 2014 to 2015 as is the case of Mostardas from 8.2 to 0.

It can be inferred that the HSI aided the IMC of Mostardas to present better results. However, it should be considered that the health and sanitation indices of the municipality can not be determined solely by the IMC. The use of this indicator as a proxy for the health status of the population is sometimes criticized for emphasizing only part of the population, to the detriment of the rest. In general, the limitations noted for its use as a health indicator include: (1) reflecting an incomplete history of the disease; (2) those diseases that weaken, but do not lead to death, are not represented; and (3) deaths are events that express only the maximum severity[20].

The poor sanitary condition as a vehicle for disease transmission is a classic correlationin the field of environmental health[21], and shown in studies developed in citiesas Vitória/ES[22], Cordeiros/BA e Saúde/BA[23].

The researchers were able to demonstrate through the continued observation of that population that, after the installation of the HSI, the contamination rate and infant mortality decreased. However, its efficiency was jeopardized by the fact that not all residents in the area were benefited by the program and the interactions between children ended up spreading the disease, despite the measure of containment.

The studies highlight that actions of environmental education and improvement of social conditions should be promoted simultaneously. In Vitoria/ES, a study was conducted to evaluate the health impacts on 
children between three months to five years of age, living in neighborhoods with home health improvements, using the epidemiological method of a case-control study to correlate the results of parasitological examination of helminths and protozoa of the groups formed by individuals benefited and not benefited by the construction of bathrooms in the residences. The stratified analysis between beneficiaries and non-beneficiaries showed no difference in the outcome of the parasitological examination of feces between the groups, however it was characterized that the conditions of the hygiene habits in both groups are precarious, evidenced by the large number of children who walked barefoot and presented diarrhea (55\%) [22].

Another of the principles of FUNASA is that, by providing households with HSI, in parallel, seek to modify the hygiene habits of the beneficiary. Int3, when asked if there was an improvement in the sanitary conditions of her residence, after being benefited with the HSI, she stated:

It helped a lot because we did not have a bathroom when we moved here. There was no way to bathe or wash our hands, and to use the bathroom we used a hole in the back of the house. Our hygiene has improved a lot with this bathroom here.

Despite the evolution in the health and hygiene conditions of the beneficiaries, the fact that the program was not carried out in parallel with actions of environmental education and health promotion compromised, in its amplitude, the benefits brought by HSIP. There is a consensus among professionals and technicians in the area on the importance of treating sanitation as an interdisciplinary area, where the connection between the Federal Government, municipality, sanitation and public health professionals, together with the population, is effective. The interviewee ExpBA explains that: "Basic sanitation provides improved public health and reduces water pollution. It should also be aware of environmental practices in the sense of reuse of materials, water and low energy consumption".

And ExpCE states, also: Most health problems affecting the world's population are intrinsically related to environmental factors. Therefore, the importance of basic sanitation for human health has a paramount relationship in sanitary control of the environment in public health actions.
With this, it can be seen that basic sanitation can not be dissociated from environmental and public health issues. Instead, one must elevate this conceptual tripod to its best level of execution. The Lagoa do Peixe National Park, located between Mostardas and Tavares, ends up suffering profound negative direct environmental impacts, due to the lack of sanitation of the surrounding towns.

The Chico Mendes Institute, responsible for the conservation of the park, points out that the cities near the place have low efficiency sanitary structures, affecting the surrounding environment[24]. There are several points with open-airsewage in the vicinity, bringing problems such as contamination of surface and groundwater, consequently reaching the park. These recurring environmental impacts could be minimized or avoided with the application of HSI in partnership with the efficiency in the management of resources made available to municipalities, as well as the investment in environmental education.

\subsection{Sanitary situation of Municipalities and HSI Versus Conventional Solutions}

Another objective of the present study was to analyze the feasibility of the use of HSI in relation to conventional solutions and its importance for sanitation and health indexes. The informant of interest of this research, identified by ExpBA, states:

The actions of HSI are actions of implantation and operation of infrastructures that allow, by means of appropriate technology, the supply of drinking water, collection and final disposal of sanitary sewage, the management of solid waste and rainwater.

For a sanitation action with lower cost and directed to the individual needs of each beneficiary, HSI is a technological alternative. Situations like this are common in small municipalities, both in their urban area, as observed in Mostardas, and in rural areas, where there is no financial or socio-environmental contribution to major engineering works. The interviewee ExpBA complements:

In rural areas, HSI provides a stool confinement, thus reducing the possibility of contamination of the water used by the population. There is also the comfort of having more and better quality water at home, without having to walk hours to bring a small amount of water. 
The SDG6 proposes that, by 2030, there is universal access to drinking water, as well as the quest to eliminate open defecation and ensure sanitation for the entire population. In this context, HSI is an ally in the scope of SDG6.In order to identify the sanitary situations of the municipalities before and after the HSIP, they were questioned how could define their pre and post HSIP condition. When compiling the results, it can be identified that, according to them, there was a change in the health situation. The municipalities that had declared themselves in Pessima, Bad or Intermediary status, began declaring Good or Intermediate(Table4).

Table4. Pre and Post HSIP: sanitary situation of municipalities according to self-classification

\begin{tabular}{|l|l|l|l|}
\hline Municipality & \multicolumn{1}{|c|}{ Sanitation Tools that have } & Pre-HSIP Situation & Post-HSIP Situation \\
\hline M1 & $\begin{array}{l}\text { Water distribution network; collection and final } \\
\text { destination of solid waste }\end{array}$ & Intermediate \\
\hline M2 & $\begin{array}{l}\text { Water distribution network; collection and } \\
\text { treatment of sewage; collection and final } \\
\text { disposal of solid waste; urban drainage }\end{array}$ & Intermediate & Good \\
\hline M3 & Water distribution network & Good & Good \\
\hline M4 & $\begin{array}{l}\text { Water distribution network; collection and final } \\
\text { destination of solid waste }\end{array}$ & Bad & Good \\
\hline M5 & $\begin{array}{l}\text { Water distribution network; collection and final } \\
\text { destination of solid waste }\end{array}$ & Poor & Intermediate \\
\hline
\end{tabular}

However, it is observed that there was some inconsistency in sanitary self-classification. M2, filling in the questionnaire, identified that in its locality there was a water distribution network, collection network and treatment of sewage, as well as collection of solid waste and urban drainage project, but it was declared as having an intermediate sanitary condition. Already M3 had only water distribution network and was declared to have a good sanitary situation.

The divergence between the self-classification criteria caught the attention and it was questioned if the municipal managers are able to identify the needs and apply, appropriately, to FUNASA for financial contribution for HSI Program. It is requested to to the municipality interested to carry out a survey of the sanitary situation. For this, the technical knowledge helps to determine more precisely the health situation of a given area.

In spite of the improvements pointed out by the municipalities in Mostardas, the beneficiary population has a divergent opinion on the resulting contribution of the HSIP, not in relation to the design of the program, but due to its construction problems. Although satisfied with having sanitary modules, water tanks and other facilities, they expressed discontent about the quality and the way in which they were carried out in their homes. The interviewee Int6, when asked if he would be satisfied with the sanitary situation after the installation, said:

No, I did not. My module was built and in less than a month it had to be disabled because the construction was poorly done and the sewage would eventually come back into the bathroom We had to demolish, since it ended up bringing more problems than benefits. And now, I do not have a bathroom again.

This dissatisfaction was repeated with another interviewee (Int1), who said: They did everything wrong. They came here to build the module in the middle of a holiday that I was not even at home. When I returned from the trip, it was already built on the wrong side of the road, away from my house.

The fact that the sanitary module has been constructed in a location that is out of position and far from the beneficiary's residence contradicts the constructive guidelines of FUNASA's own manual. In this manual, it is made explicit that the sanitary unit should preferably be built indoors or integrated in the home to facilitate the access of the residents, making HSI a useful and participatory part of the lives of families. In this case, the module was only used later, when the beneficiary's daughter built a house, encompassing the HSI to its residence. The beneficiary Int 2 reported that the HSI delivered had no water box or connection with the water supply network and that the construction of this water tank was made by the beneficiary himself, seeking to "give utility to the bathroom."

The sanitation professionals and technicians of FUNASA agree with the population regarding the constructive problems of HSI. When asked on difficulties forits implementation, they point to the low quality of work, as asserted ExpCE: 
In some cases, contracted companies do not complete the works or execute them with materials of very poor quality, which end up harming the population and making difficult the supervision of the work.

The constructive problems suggest the need to discuss the aspects of management and oversight of the program, either by FUNASA or by municipality. The ExpCE comments that one of the biggest problems of HSI's actions is the lack of supervision in the works and its consequent overbilling:

In my view, the greatest difficulty in developing HSI is the high cost of sanitary improvements that are carried out by construction companies that always supercharge works to benefit municipal managers because they are not supervised.

This set of situations ends up contributing to the problems of project execution, resulting in sanitation solutions compromised by poor management of financial resources.

The municipalities, when asked about the reasons for choosing the HSIP, rather than conventional actions, say, as M4:

It was chosen because it is a faster and cheaper type of health action. Our municipality has no way to carry out major sanitation works because of the difficulty in executing the project and releasing funds. So HSI seemed to be the best option.

M1 said have chosen HSI because there is an expressive rural population in his locality that does not have access to basic sanitation: "We chose HSI because of ease of deployment, low cost, and the ability to bring basic sanitation to places farther from the urban center".

This demonstrates that agility in carrying out the action, its easy implementation, and the lower need for large financial contributions make HSI more feasible to execute, in the short term, than projects of greater complexity, especially in small municipalities. Some municipalities also considered that HSI values and empower the population receiving the benefit, as quoted by M1:

We chose the HSI, because it is a more individualized action that besides the sanitary benefit, brings significant improvements in the issues of hygiene and self-esteem of the beneficiary population.

The HSIP would express the concept of appropriate technology that relates the infrastructure to the needs of its users and their appropriation by the community. With the evidences presented, it was possible to assemble Table 5, where it was determined the positive points and the facilities, besides the negative points and problems in using the HSIP.

Table5. Positive and Negative Aspects of Using the HSI Program

\begin{tabular}{|l|}
\hline \multicolumn{1}{|c|}{ Positive Aspects } \\
\hline a. Faster execution and lower cost \\
b. Engineering geared to the specific needs of the \\
beneficiary \\
c. Prevention and control of diseases \\
d. Higher productivity and quality of life of the \\
beneficiary \\
e. Decrease child mortality rates \\
f. Reduces water pollution and environmental \\
contamination \\
g. In its conception, a technology to be \\
appropriated by the user/community \\
\hline
\end{tabular}

Despite the recurrent problems, HSI finds its application and efficiency as an alternative to conventional actions and can be a determinant vector for the modification of the Brazilian sanitary framework. Evaluating social interventions, and in the area of sanitation specifically, is a step of significant importance in the process of planning actions and decision making by the public power, since this type of research produces information about the direct influence of governmental actions on society [21]. a. Poor build quality of sanitary modules

b. Lack of interest from political sectors in solutions other than conventional

c. Lack of environmental/health education to the population results in poor use of HSI

d. Overbilling of works

e. Lack of investment in HSIP

\subsection{Importance Of Municipal Sanitation Workshop (MSW) to the Effectiveness of HSIP}

The HSIP implementation manual requires MSW to be developed, in parallel, the construction of the equipment. In order to identify the role of this tool for the better development of HSI together with sanitation technicians and professionals, the question of the importance of the workshop and how it benefits the local population was questioned. ExpCE asserts: 
The MSW, if adequately equipped according to FUNASA standards, functions as a School of Public Health, preparing and guiding families to understand the benefits of HSI. It also serves as control and organization of the sanitation works to be carried out in the municipality.

The WHO aims to share with the beneficiary the understanding of local environmental problems, their relationship to public health and the best use of HSI. It should be used as a knowledgebuilding space, making the population active during the implementation of the program. It can also be seen as a place of economic incentive, when stimulated social participation in the making of sanitary ware and other utensils used in the installed sanitary modules. Community empowerment involves broad participation of individuals in decision-making processes, as well as actual or potential achievement of material resources or power, such as social rights, and health promotion being an expression of them [25,26,27].

Moving the local economy is a dimension to consider when assessing the importance of the MSW-HSI combination. Those involved with the program acquire knowledge and through it have the possibility to improve their financial condition. In the specific case of Mostardas, the municipality is composed mostly of economically disadvantaged people, for whom the social priorities are not health and the environment. It was noted that the majority of the beneficiaries interviewed were unemployed, which would make MSW an option as a promoter of the local economy.

On the other hand, ExpCE highlights the fact that MSW serves as a space of social control over the works. With the population engaged in the program, it is possible to more actively supervise the works in execution. In this context, Int3 states: "We have to be informed of what the prefecture does. We can not just vote, we have to charge what was promised, because after all, it's our tax money being used".

It is observed the recognition of the capacity of the population to be a fiscalizing agent, willing to exercise this role aiming at the best investment of the public resources and, consequently, a better execution of the actions for the sanitation area. ExpBA, when asked about the importance of MSW, states:

Environmental Education is fundamental to the HSI Program, because if the population is not inserted in the environmental context, it will not perceive the advantages and consequently, it will not use the HSI.

Despite of importance of the MSW for the implementation of HSI, all municipalities interviewed reported that they had not carried out the MSW in their localities and had not been charged by FUNASA. Even without the development of this tool, there is awareness among the interviewees of the importance and benefits that come, as M4 states:

The MSW would be very welcome here in the municipality because it would increase the population's awareness of the benefit (HSI) that was given (sic), and increase social responsibility. It would make the environment and health here certainly better, because we would be better able to guide them.

Non-implementation of MSW may have contributed to the divergences found in municipal sanitary self-classifications, in view of the fact that sanitary conditions assessments should be carried out by trained municipal agentsby the MSWs. When discussing this topic with the population benefited from Mostardas, it was noted that MSW was never even mentioned. Int2, when asked about its importance, comments:

No one commented on me about this MSW. Here it is very difficult to give us information, they do not care if we do not know about things [...] Sometimes we have a meeting at the Residents' Association and I tell people we should worry about picking up the waste and taking care of the sewage here from the street, but nobody does their part. I think because they do not know about it, the population does not care.

This testimony shows a recurrent situation in the interviews with the beneficiaries, when they affirm that there was no participation during the implementation of the HSI Program and that the lack of knowledge made them oblivious to the benefits that could be obtained.

\subsection{FUNASA as Inductor Vector for Public Policies in Public Health and Sanitation}

The study aimed to analyze the role of FUNASA as a vector of change in the Brazilian sanitary scenario. We first sought to characterize the role of the institution and its actions in the area of sanitation and public health, and then to determine the difficulties it would encounter in 
becoming this vector. The ExpCE interviewee offered a historical perspective, describing the context of FUNASA's emergence. Prior to its creation, when still called the SESP Foundation (Special Public Health Service), it had as its purpose the preventive actions, through basic sanitation, as well as curative assistance to the rubber tappers in the Amazon. After the end of World War II, the Federal Government extended the foundation's actions to other disadvantaged municipalities outside the Amazon region. For decades, basic sanitation actions were implemented with the participation of communities, through the sanitation workshops, installed in their Health Workshops.

Heiress of this history, possessing the technical and empirical knowledge, FUNASA is created with the role of fomenting new sanitation policies, being able to direct them as needed. ExpCE adds: "FUNASA would play the role of coordinating and supervising sanitation actions, guiding the Government in identifying the needs of the sector and better developing its public policies".

However, it is observed that this knowledgeproducing and disseminating role has not been fully realized. ExpCE explains that prior to the merger between the SESP Foundation and the Public Health Campaigns Superintendence (SUCAM), which would originate it; these agencies had as priority the realization of health education, guiding the community to build their own HSI equipment, within of the MSW, making the families value the benefit by knowing their importance. ExpCE further states:

With the merger there was a radical change in the policy of sanitation actions, from the community participation to total financing of the HSI by the government. The costs for basic actions have tripled and the purpose of the educating agency has been lost.

This lack of guiding power on the part of FUNASA results in technicians losing sight of the institution's first mission. When the ExpRS was asked about the importance of the Sanitation Workshop being developed in parallel with the HSI, he states: "The goal of the HSI Program is to deploy individual and collective small-scale solutions with appropriate technologies, so MSW's use is not necessary in all situations".

An institution with the mission of promoting public health and social inclusion through sanitation actions will not be able to develop a health program without proper guidance to its participants. All HSI Program's actors should be active, both as supervisors of good progress of the program and identifying opportunities for improvement. In order to address the challenges the foundation faces in promoting sanitation policies in Brazil, technicians and operators in the area were questioned. ExpCE considers:

First, there is no public sanitation policy without the effective participation of the community. I consider this factor one of the main problems in the sector. I also see that the lack of commitment of the municipal managers with the area, hinders the development of sanitation.

While ExpRS points out:The biggest difficulty I see is the availability of financial resources to invest in sanitation, especially in rural areas and remote communities. Another problematic factor is that in some situations it is not possible to meet FUNASA's standard project, especially in works involving sewage, as there are large differences between soil types, throughout a country such as Brazil, and their way of building septic tanks and sinks.

And ExpRS is complemented by ExpBA: I believe that the greatest difficulties are the lack of interest of some public sectors in providing situations that release the population from their sphere of dependence, beyond the lack or little information of the beneficiaries about the advantages of HSI.

Different reasons were found for FUNASA's low efficiency in fulfilling its role. Municipal managers prefer to streamline the process and obtain the release of the public resource than to seek technical knowledge, which would ensure efficient investment. The projects designated by FUNASA for HSI do not have the necessary flexibility to meet the soil type, porosity, water regime or climate of the different regions of the Brazilian territory. The manual presents options for execution, however without clarification as to the possibility of changing constructive specifications, resulting in inappropriate and inefficient equipment.

This analysis is supported by Klingerman[28], for whom FUNASA's logic of creation did not take into account the logic of Brazilian Sanitary Reform, consolidated from the $8^{\text {th }}$ National Health Conference (1986), nor the need for reordering institutional structure of the sanitation sector, which continues with 
attributions pulverized in several institutions. The logic turned out to be an Administrative Reform, being more like an executor, less the one of decision maker, and distant of its initial proposal, educator in sanitation and health.

FUNASA would need to return to its original goal in line with the SUS (Brazilian Unified Health System), in view of the basic principles of this: universal access, comprehensive care and fairness of service provision[29]. Analysis complemented by ExpRS:

FUNASA's mission would be to carry out environmental sanitation actions in all municipalities with less than 50,000 inhabitants, promoting public health and social inclusion in line with the SUS, the Millennium Development Goals (MDG) and Sustainable Development Goals (SDG).

This collaborative work FUNASA/SUS would lead to better execution of basic sanitation. Synergy is aligned with MDGs 4 and 7 which, respectively, determine the reduction of infant mortality and the improvement in quality of life and the environment[30].In additionally, this perspective is also alignedwiththe SDGs 6 and 11 that seek, respectively, ensure the access to safe water and sanitationfor all and make cities and human settlements inclusive, safe, resilient and sustainable[31].

\subsection{Main Study Limitations}

It is necessary to express the limitations identified in the study for future developments: (1) socio-demographic survey: the addition of information in a future application of the questionnaire about the beneficiaries of the HSIP, such as: gender, occupation, income and residence time in the local; (2) it was chosen, due to constraints in the schedule, not to perform pre-tests for the adjustment of the interrogation instruments; (3) data retention by FUNASA: upon requesting access to data from selected municipalities, guidance was received on completing the Form for Request for Access to Information, available on its website. Until the date of conclusion of this study, no response was received.

\section{CONCLUSION}

The study brings evidence that demonstrate the feasibility and importance of home sanitary improvements (HSI) versus conventional solutions. HSI has shown to be an alternative to be used when there is a need for individualized sanitation actions, acting on the environmental and sanitary conditions of the contemplated population. It was also observed its feasibility when agility is required in the execution of engineering actions and a small financial contribution is available, considering that HSI presents a low cost when compared to conventional solutions.

However, constructive problems were identified in the sanitary modules. The mould on the premises, the lack of connections with the water network and water tanks and the problems with the passage box, sump and cesspool, implied in its disuse. These situations may have occurred due to lack of supervision by FUNASA and the municipality during the execution of the works and/or by the lack of environmental education programs and health promotion accessible to the community.

There was no combination of the use of physical structures (engineering works) with educational, legal and social structures in the case of the Municipality of Mostardas. Although the evidence demonstrates the construction of the HSI, even if with problems of execution, it was not possible to identify any sign of the MSW development in the municipality.

FUNASA, in its current form of action, partially fulfills its role as an induction vector for public policies in the area of basic sanitation and Public Health. The agency does not guarantee the execution with quality of the sanitary improvements, nor does it verify if the program is being developed according to the information passed on by the municipality, through a photographic report. At the conclusion of this study, one can leave as suggestions for FUNASA:

- The search for a more transparent profile, facilitating access to information about its programs so that it has the opportunity to execute them efficiently and effectively;

- Rethinking the technical formatting of the projects to better adapt to the different situations encountered in the different regions of the country, and to be developed regionally manner;

- Encouraging intersectoral partnerships, since it is seen that experience and knowledge, both technical and practical, bring benefits to 
the program and broaden its horizons of execution.

FUNASA has a preponderant role in: (1) fostering environmental health education and social mobilization in sanitation, (2) stimulating socio-environmental sustainability, (3) technical support, (4) encouraging studies and research with a view to the search for new tools and strategies and (5) work integrated with the Brazilian Unified Health System (SUS).

Keeping in the way of acting here reported, the agency will continue to face difficulties in being an agent of necessary changes in the sanitary reality of Brazil. Information and knowledge must be linked to the engineering actions, to the better functioning of the projects and the consequent alteration of the sanitation and health indices in the national territory.

\section{Authors' CONTRIBUTIONS}

Fontela was responsible for project design, data collection, data analysis and paper writing. Chaves guided all the steps of the work and participated in the review and writing of the project and of the paper. Almeida and Welzel participated in the review and writing of the paper.

\section{REFERENCES}

[1] Ferriman A.BMJ readers choose sanitation as greatest medical advance since 1840 . British Medical Journal. London. 2007; 334:111. [Cited 2016 May 27]. Available from: http://www.bmj.com/content/334/7585/111.2.

[2] Britto AL. Mudanças climáticas, saneamento básico e governança da água na Região Metropolitana do Rio de Janeiro. 2010. [Cited 2016 Oct 18]. Available from: http://www. anppas.org.br/encontro5/cd/artigos/GT11-532488-20100903235031 .pdf.

[3] ITB. Instituto Trata Brasil. Relatório de Olho no PAC. 2015.[Cited 2016 Mar 24]. Available from:http://www.Tratabrasil .org.br /datafiles /de-olho-no-pac/2015/De-Olho-no-PAC-2015relatorio. pdf.

[4] DataSUS. Departamento de Informática do SUS. Dados da Saúde. 2013. [Cited 2016 Mar 11]. Available from: http:// tabnet.datasus. gov.br/cgi /deftohtm.exe? recsus /cnv/rsrs.def.

[5] Pimentel CEB, Cordeiro Netto OM. Proposta Metodológica de Classificação e Avaliação Ambiental de Projetos de Saneamento. Brasília: Instituto de Pesquisa Econômica Aplicada. 1998. [Cited 2016 Apr 20]. Available from: http://www.scielo.br/pdf/csp/ v18n6/13268.pdf.
[6] ONUBR. Nações Unidas no Brasil. 17 Objetivos para transformar nosso mundo (ODS). 2015. [Cited 2016 Oct 25]. Available from: https://nacoesunidas.org/pos2015/.

[7] IBGE. Instituto Brasileiro de Geografia e Estatística. SIDRA. Censo Demográfico: Tabela 1290 - Número de municípios e População nos Censos Demográficos por tamanho da população. 2016. [Cited 2017 Sep 20].Available from: https: //sidra .ibge. gov .br / tabela/1290.

[8] Brasil. Constituição da República Federativa do Brasil. 1988. [Cited 2016 Apr 01]. Available from: http: //bd. camara. gov.br /bd/ handle /bdcamara/15775.

[9] Silva LDB. Saneamento Básico. 2007. [Cited 2016 Mar 01]. Available from: http:// www. ufrrj.br/institutos/it/deng/leonardo/donwload.

[10] FUNASA. Fundação Nacional de Saúde. Manual de Orientações Técnicas para Elaboração de Propostas de para o Programa de MSD da FUNASA. 2014. [Cited 2016 Apr 14]. Available from: http:// www. funasa. gov. br/sit e/wp-content /files_ mf/ manuald eorienta coestecnicasparaelaboracaodepropostasmelh or iassanitariasdomiciliares.pdf.

[11] FUNASA. Fundação Nacional de Saúde. Avaliação Comparativa dos Impactos à Saúde das Crianças nos Bairros Contemplados com Melhorias Sanitárias Domiciliares. 2010. [Cited 2016 Mar04]. Available from: http:// www. funasa.gov.br/site/wp-content/ files_ mf/aval CompaSaude Criancas.pdf.

[12] Merhy EE. Um ensaio sobre o médico e suas valises tecnológicas: contribuições para compreender as reestruturações produtivas do setor saúde. 2000. [Cited 2016 Mar 22]. Available from: https://edisciplinas.usp.br/ $\mathrm{pl}$ uginfile.php/114174/ mod_resource/ content/2/ Merhy\%20ensaio\%20valises\%20tecnologicas. pdf.

[13] Juliano EFGA, Feuerwerker LCM, Coutinho SMV, Malheiros TF. Racionalid adees aberesparaa universalizaç ão do saneamento em áreas de vulnerabilidade social. 2012. [Cited 2016 Mar26]. Available from: http:// www.s cielo. $\mathrm{br} / \mathrm{sci}$ elo.ph p?script $=$ sci_artte $\mathrm{xt} \& \mathrm{pid}=$ S1413-812320 12001100020.

[14] Foucault M. Microfísica do Poder. 2014. [Cited2016Mar24].Available from:http://ww w. nodo50.org/insurgentes/biblioteca/A_Microfisi ca_do_Poder_Michel_Foulcault.pdf.

[15] Cavalcante RB. Análise de Conteúdo: considerações gerais, relações com a pergunta de pesquisa, possibilidades e limitações do método. Inf. \& Soc.: Estudos. João Pessoa/Pb. 2014; 24(1):13.

[16] Bardin L. Análise de conteúdo. Lisboa: Edições 70, 2006. [Cited 2016 Sep 15]. Available from: 
http:// www.scielo. br/pdf/ reben /v57 n5/ a19v 57n5.pdf.

[17] Campos CJ. Método de Análise de Conteúdo: ferramenta para a análise de dados qualitativos no campo da saúde. Ver. Bras. Enferm. Brasília/DF. 2004; p.611-4.

[18] TCE/RS. Tribunal de Contas do Estado do Rio Grande do Sul. Relatório sobre o Plano Municipal de Saneamento Básico e Plano de Gestão Integrada de Resíduos. 2014.[Cited 2016 Oct 20].Available from: http:/ /www.tce .rs.gov.br/docs/ RelPlano Sanea ment o Re sSo lidos.pdf.

[19] Jornal Correiodo Povo. RS registra a menor taxa de mortalidade infantil da história. Jornal Correrio do Povo. Porto Alegre. Abr. 2016. [Cited 2016 Nov 04]. Available from:http://www.Correio do p o vo. Com .br/N oticias/G eral/Saude/20 16/4/583765/RSregistra-a-menor-taxa-de-mortalidade-infantilda-historia.

[20] Oliveira SM. Mortalidade infantil e saneamento básico: ainda uma velha questão. XVI Encontro Nacional de Estudos Populacionais.2008.[Cited 2016 Nov 01]. Available from: http://www. abep. nepo. unicamp.br/en contro20 08/do csPD F/ABEP2008_959.pdf.

[21] Heller L, Moraes LRS, Monteiro TCN, Salles MJ, Almeida LM, Câncio J.Saneamento e saúde nos países em desenvolvimento. Rio de Janeiro: CC\&P Editora, 1997.

[22] Resende MB. Implantação de melhorias sanitárias domiciliares no município de Vitória/ES. 2012. [Cited 2016 Mar 23]. Avai label from: http://www.trabalhos feito s.co/ ensaios/Implantação-De-Melhorias-Sanitár iasNo-Munic \%C3\%ADpio/2977 49.html.

[23] Orrico, S. Melhorias Sanitárias e seu Uso Apropriado. $23^{\circ}$ Congresso Brasileiro de Engenharia Ambientale Sanitária. 2005. [Cited2017Sep27]. Available from http:// www. bvsde.paho.org/bvsa cd/ abes23 /VII-019.pdf.

[24] ICMBio, Instituto Chico Mendes. Plano de Manejo do Parque Nacional da Lagoa do Peixe. 1999. [Cited 2016 Oct 05]. Available from: http://www.icmbio.gov.br/portal/images/stories /imgs-unidades-coservacao/parna_lagoa-dopeixe.pdf.

[25] Brown C, Heller L. Development cooperation in water and sanitation: is it based on the human rights framework?.Ciênc. Saúde Coletiva. 2017; 22(7):2247-2256. [Cited 2017 Sept 28]. Available from: http:// www. Scielo .br/scielo.php? script= sci_arttext\&pid =S141381232017002702247\&lng=pt\&nrm=iso.

[26] Neves-Silva P, Heller L. O direito humano à água e ao esgotamento sanitário como instrumento para promoção da saúde de populaçõesvulneráveis. Ciênc.Saúde Coletiva. 2016; 21(6):1861-1870. [Cited 2017 Sep 28]. Available from: http:/www.s cie losp.org/ scielo.php?script=sci_arttext\&pid=S1413-812 $32016000601861 \&$ ln $\mathrm{g}=$ en \&nrm=iso.

[27] Carvalho, S.R. Saúde coletiva e promoção da saúde: sujeito e mudança. São Paulo: Hucitec, 2005.[Cited2017Sep27].Available from: http:// www.scielo.br/scielo.php?script=sci_arttext\&pi $\mathrm{d}=$ S0102-311X 2007000100029.

[28] Klingerman DC. Esgotamento sanitário: de alternativas tecnológicas a tecnologias apropriadas- uma análise no contexto brasileiro. Instituto de Pesquisa e Planejamento Urbano e Regional. 1995. [Cited 2016 Nov 01]. Available from: http:// pesquisa.bvs.br /brasil /resource /pt/l il-398521.

[29] Arreaza ALV, Moraes JC. Vigilância da saúde: fundamentos ,inter facesetendênci as. Ciênc. SaúdeColetiva.2010;15(4):2215-28. [Cited 2016 Nov01].Available from: http://ww w.scie lo.br/ scielo.php?script=sci_arttext\& pid= S1413$81232010000400036 \& \operatorname{lng}=$ en\&nrm=iso.

[30] ONUBR. Nações Unidas no Brasil. Objetivos de Desenvolvimento do Milênio (ODM). 2016. [Cited 2016 Nov 01]. Available from: https://nacoesunid as. Org / tema/odm/.

[31] UN.United Nations .Sustainable Deve lopm ent Goals: sustainable develo pment knowledge platform. 2017. [Cited 2017 Sep20].Available from: https://sustainab led evelopment. un.org/? $\mathrm{m}$ enu $=1300$.

Citation: André Preissler Loureiro Chaves, Bruna de Souza Fontela, Márcia Maria Nascimento de Almeida \& Albert Welzel. Home Sanitary Improvements Program as Vector of Change in the Brazilian Public Health Scenario: A Strategy for the Fulfillment of a Human Right. ARC Journal of Public Health and Community Medicine.2018; 3(1):13-25. DOI: dx.doi.org/ 10.20431/2456-0596.0301003.

Copyright: (c) 2018 Authors. This is an open-access article distributed under the terms of the Creative Commons Attribution License, which permits unrestricted use, distribution, and reproduction in any medium, provided the original author and source are credited. 